\title{
GALILEO'S METHODOLOGICAL VERSATILITY IN THE DEVELOPMENT OF HIS PHYSICS
}

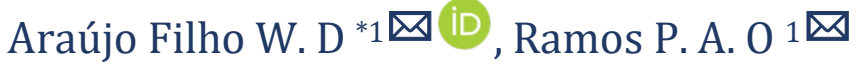 \\ ${ }^{*}$ S State University of Bahia (UNEB) - Collegiate of Physics-Department of Exact and Earth Sciences \\ (DCET 1) - Micro fluidic laboratory (LAMIC), Brazil
}

DOI: https://doi.org/10.29121/granthaalayah.v8.i9.2020.1384

Article Type: Research Article

Article Citation: Araújo Filho W. D, and Ramos P. A. O. (2020).

GALILEO'S METHODOLOGICAL VERSATILITY IN THE DEVELOPMENT OF HIS PHYSICS. International Journal of Research GRANTHAALAYAH, 8(9), 87-95. https://doi.org/10.29121/granthaa layah.v8.i9.2020.1384

Received Date: 02 September 2020

Accepted Date: 29 September 2020

Keywords:

Galileo

Empiricism

Rationalism

Epistemology

Historicism

\section{ABSTRACT}

Galileo's way of doing science is very controversial. Some historians interpret their work in the light of empiricism, that is, science constructed through sensory data interpreted in the light of logical-mathematical reasoning. Others interpret their work under the aegis of rationalism, by means of which science is constructed, a priori, starting from reality, through pure hypothetical-deductive reasoning. In this view, Galilean experimental incursions played a secondary role in the development of his work. Therefore, two distinct forms of interpretation arise and an asymmetric view of doing science. The scientific method is seen as a recipe, and in an attempt to obtain explanations that best approach reality and achieve true knowledge, it is imperative to follow certain pre-established rules or predetermined restrictions. In contrast, sectarian-free interpretations clarify and promote the genesis of Galilean thought, taking it to a much more complex and lavish level. Some interpretations suggest raising the condition of Galileo to genius and not to a great talent, without observing that the difference between them lies in the addition of intuition to talent, an indispensable ingredient for the transposi-tion between the empirical and rational instances at the right time, so natural to geniuses. According to this point of view, Galileo's work challenges the thesis of being an asymmetric and closed process, replacing it with a dialectical bias, giving intuition and imagination essential roles in the development of his work, hence the genius of his work. personality. This work seeks to understand the genesis and motivations inherent to Galileo's works and the impossibility of compartmentalizing his activity, thinking and originality in narrow and imprecise molds.

\section{INTRODUCTION}

What underpinned the development of Galilean science? Did it establish itself from rationalism or empiricism? Were there external factors, implicit or not, that motivated its construction? The attempt to decode a brilliant, creative, kaleidoscopic mind and deeply imbued with the multifaceted ideals of the Renaissance is a thorny task, if not impossible. However, in the case of Galileo, three intricacies seem to converge and feed his creative flow, allowing for a necessary reflection for this purpose: the singularity of the historical moment in which he lived, the strong paternal influence and the frequent circumstantial drives that fostered his skills as an engineer and craftsman. For that, a brief summary will be made about this amalgam that would shape your mind, life and work.

(C) 2020 The Author(s). This is an open access article distributed under the terms of the Creative Commons Attribution License, which permits unrestricted use, distribution, and reproduction in any medium, provided the original author and source are credited. 
The historical moment pertinent to the present discussion is at the end of the 16th century and the beginning of the 17 th century, a period marked by profound social, technological and scientific transformations, above all in the way man faces the world. In this perspective, the paradigms of science established and spread over more than 1000 years have changed, with the church playing an important role in sedimenting ideas through economic power and the rigid establishment of dogmas. Ideas that permeated the established scientific community are beginning to be denied or questioned.

\subsection{THE HISTORIC MOMENT AND CREATIVITY}

Galileo lived in the epicentre of an era marked by exceptional creative power, rich in exciting and dramatic changes in the fields of arts, literature, social patterns, dissemination of knowledge, science and discoveries - the Renaissance. New continents were discovered by the great navigators, unknown peoples and cultures came to light. A legion of painters, sculptors and architects like Leonardo da Vinci, Rafael, Bramante, Michelangelo, Brunelleschi, Giotto, Donatello; William Shakespeare, Camões, Cervantes, Petrarch and Giordano Bruno's thinkers, Francis Bacon, Rotterdam Erasmus, Thomas Mo-re and others, revolutionized the way of seeing, thinking, interpreting and reconstructing creatively the world.

Deeply influenced by Renaissance art, Galileo tried early to give rise to his creative vein through music and painting and, at the end of his life, confided to his closest friends the deep desire that he had, since his youth, to be a painter, overshadowed only by his passion for mathematics. [1]

\subsection{PATERNAL INFLUENCE AND MATHEMATICS}

From his father - Vincenzo Galilei, talented instrumentalist and composer - Galileo inherited his passion for music and, indirectly, for mathematics. Creator of a "revolutionary vision of music" [1] that associated arithmetic with the study of this art, Vincenzo became famous inside and outside Italy for his practical studies on materials and acoustics in string instruments (Galilei V. 1581). According to Settle [2], the observation of paternal eagerness in solving problems that combined intellect, experimentation and manual skill must have decisively influenced Galileo as a child. Giorgio Vasari (1622-703), a disciple and one of his first biographers, reports that as a child Galileo was already capable of building some mechanical models, such as mills and other devices.

It should be noted that during the Middle Ages and even in the Renaissance, mathematical arts, or quadrivium (geometry, astronomy, arithmetic and music), were taught to knowledge seekers in universities in a watertight way, dissociated from each other, contrary to the originality of Vincenzo Galilei.

Quite possibly, in the curious and eager mind of young Galileo, the influence of an absolutely abstract and rational being, like mathematics, on something tangible that had the power to transform and enliven the soul provided by music, was something magical. , divine, that would leave indelible marks and would decisively influence the way you see Nature, the Universe [3].

His interest in mathematics became more intense, when he was still a medical student, with the lessons of Ostilio Ricci (1540-1602), court mathematician in Pisa specializing in Euclidean geometry, in addition to a great friend of Vincenzo. It was during this period that his admiration for the works of Archimedes emerged, which greatly impressed him, to the detriment of Aristotle's ideas. Time would intensify this distance, fuelled by another important paternal contribution: refusal of untested ideas.

In fact, Galileo's life was marked by the importance and ubiquity of questioning, scepticism, of examining things per se, regardless of the opinions of others and the authorities. Vincenzo was particularly impatient with people whose beliefs were based on superstitions, authorities and untested ideas, which earned him a reputation as a "rebel "thinker" [1]. It is not surprising that, during his student years at the University of Pisa, young Galileo was called "Il Attaccabrighe" (polemicist, argumentative, quarrelsome) by teachers and colleagues.

\subsection{SKILL AND EXPERIMENTATION}

Maritime expansion, trade, economic competition, wealth growth (although concentrated in the hands of powerful families or autocratic public managers), military engineering and urbanization of cities were decisive 
elements for the flourishing of liberal arts during the Renaissance. In the face of growing demand, it became imperative to train good craftsmen, artists and skilled labour.

The favourable economic situation stimulated the proliferation of workshops, oriented to the arts - in which architecture and engineering are included - which ultimately aimed to creatively and practically solve emerging problems related, above all, to decoration , architecture, urbanism, navigation, the advent of firearms and their close relationship with foundry and ballistics, the building of fortresses and the necessary connection with the study of the stability and resistance of materials. The emergence of new professions and the development of infrastructure in cities - streets, bridges, ports, water regulation, etc. - responded to the specific needs imposed by regional, political or economic power differences, like the garden of Pratolino, by the Duke of Tuscany, with its myriad of automata, pneumatic devices and water organs that made up the most sophisticated hydraulic system of the time [4].

The education of artists, architects, engineers and mathematicians in the workshops enabled them in practical geometry and arithmetic, geodesy (measuring curved surfaces), static, stereometry (calculating the volume of solids), perspective and technical drawing. Art and mathematics were inextricably linked. Sculpture and painting were linked, since they were born from the same father who was drawing [5]. The workshops also housed future artisans, blacksmiths, glaziers, carpenters and shipbuilders, enabling them to move through different areas before definitive specialization. Combining opportunity, knowledge and practice, a promising generation of manufacturers of lenses and mirrors, mathematical instruments and others intended for astronomical, cartographic and navigation measurements, as well as manufacturers of wood and metal machines and devices began to emerge in society.

Financial difficulties and friendship with Guiobaldo del Monte (1545-1607) would end up arousing in Galileo a strong interest in matters of practical order and redirecting his path. As a professor at the University of Padova, Galileo opened a workshop at his home aimed at teaching military fortifications and building mathematical and military instruments (Figure 01).

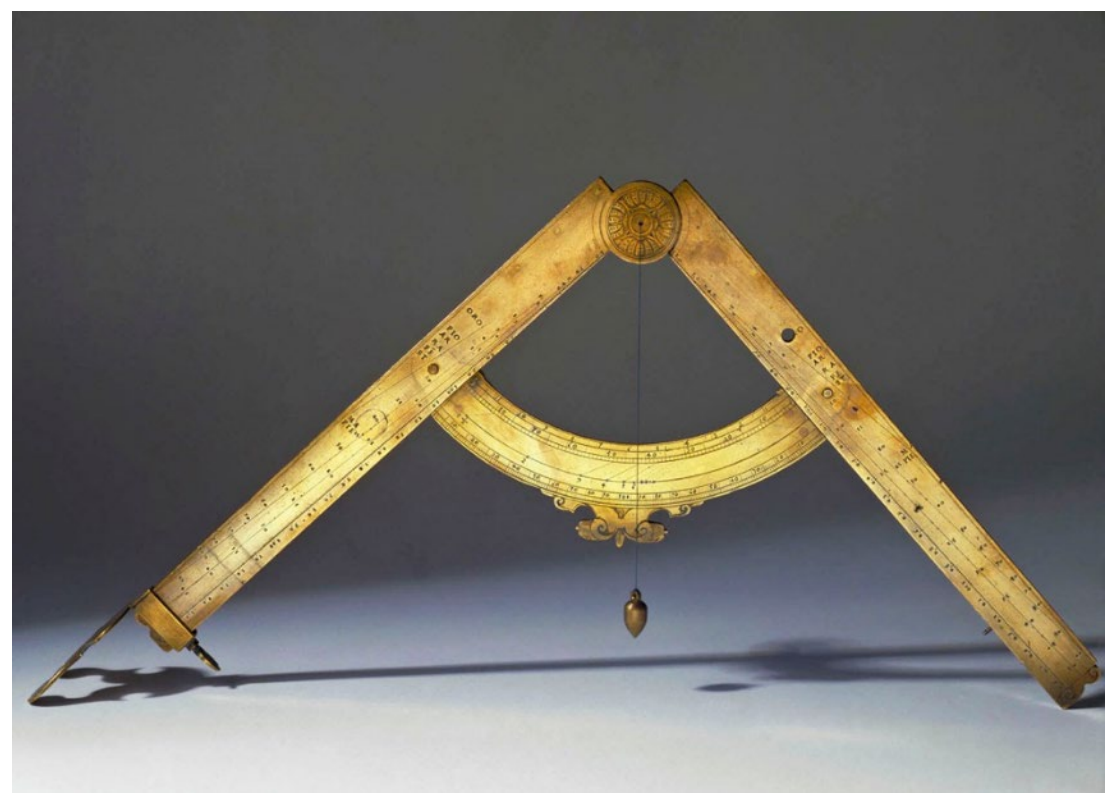

Figure 1: Galileos's first commercial scientific instrument, the geometric and military compass, described in Le operazioni del compasso geometrico et militare (1606). (Istituto e Museo di Storia della Scienza, Florence)

Thanks to his training and skills, it was possible to build a structure that attracted apprentices of different shades - mathematicians, philosophers, artists, military engineers and artisans -, while becoming a specialist in the construction of optical instruments and machines, especially those focused on defence and life in fortresses [4].

In 1599, its production of military equipment was already quite solid and well established. He also began to teach private lessons inherent to fortifications, in which he addressed topics such as the use of mathematical instruments, practical arithmetic and geometry, military architecture, machine science, technical drawing, elements of astronomy and geodesy (Figure 02). 


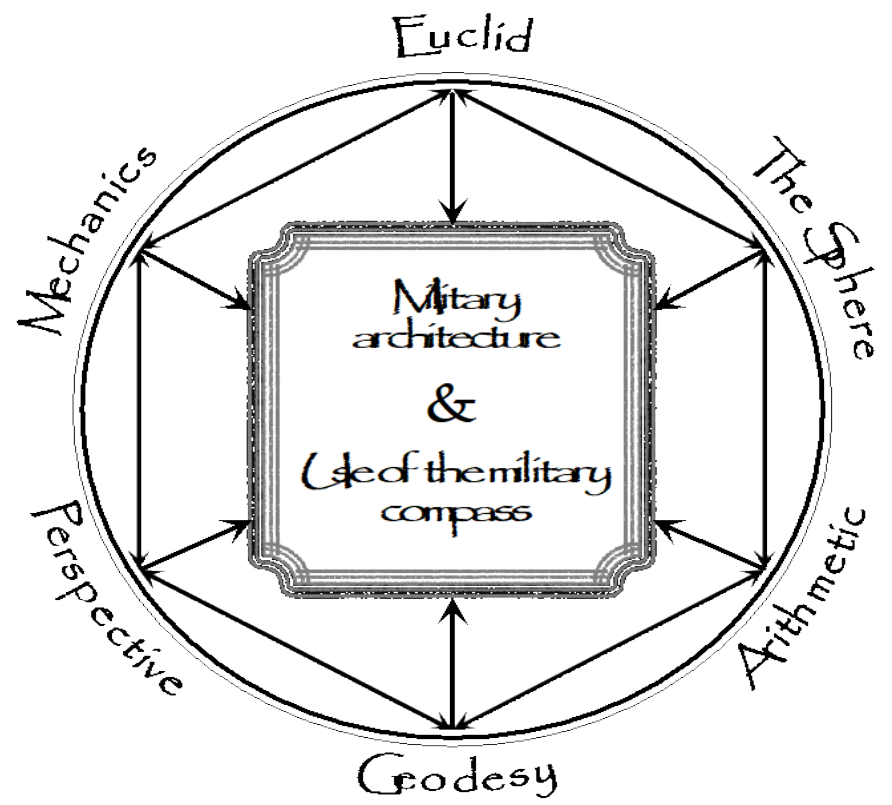

Figure 2: Structuring matrix of Galileo's course on fortifications. Adapted from VALLERIANI, M. Galileo Engineer, p. 75.

Galileo's engagement in the practical activities of his time, aimed mainly at his own livelihood, would ultimately have a decisive influence on his scientific production. Studies reveal that, underlying his theoretical investigations on the free fall of bodies, there was a practical and well-defined interest related to artillery [4]. Similarly, his studies on hydrostatics and floating bodies had as their central motivation issues related to metallurgy and bell casting [6], [7], [8].

Galileo actively participated in this period when he publicly defends the ideas of Nicolau Copérnico published in the Revolutionibus Orbium Coelestium ${ }^{1}$ in 1553, the year of his death. In this way, he takes a stand against established ideas and traces his own path paving his conception of the world.

This conception is strongly linked to the careful observations of phenomena, with mathematics playing a fundamental role in their interpretation. He synthesizes his convictions in this regard through the famous phrase: "Nature communicates with man through the Mathematic language" [9]. Such a statement had a notorious reach, establishing an inseparable and irrevocable character between the Philosophy of Nature (as Physics was then known) and Mathematics, allowing science the necessary cognitive leap in the interpretation of the physical world.

The controversial positioning in the way of doing science goes back to antiquity, based on the empiricist and rationalist conceptions. While the first values experimentation as much as possible in order to understand Nature, the second defends the powers of intelligence and reasoning in the construction of scientific knowledge.

In the case of Galileo, this discussion deepens and heats the interpretations of his legacy, often covered by the cloak of sectarianism and high content of asymmetry. It is within this perspective that scholars of his work come to assume singular positions and positions based on his particular point of view.

\section{RATIONALISM X EMPIRICISM}

\subsection{RATIONALISM}

In the defence of Rationalism, Alexandre Koyrè stands out as one of the greatest defenders of this current. For him, Galileo - hardly needed to make use of the experimental expedient and, if he did, it was through rationally planned experiments, that is, elaborated a priori with a high content of abstraction [10].

1 From Revolutionibus Orbium Coelestium (From the Revolutions of the Celestial Spheres), by the Polish astronomer Nicolaus Koppernik (1473 - 1543), better known by the Latinized name Nicolau Copérnico, published on May 24, 1543 presented an alternative cosmological model (Heliocentric System) to that of Ptolemy (Geocentric System). 
In the Torre experiment, for example, still according to Koyrè, Galileo did not have to resort to the device of launching heavy bodies from the top of the Tower to demonstrate that bodies of different masses, contrary to what the Aristotelians preached, did not fall with speeds proportional to their own. masses, but rather together. The difference in fall times was due to the resistance that the air imposed on them, hindering the downward movement.

In another imaginative foray, Galileo brilliantly refutes the idea of the immobility of the Earth according to which a stone thrown from the top of a tower would always fall at the foot of it as a result of Earth state of rest. In counter argument, Galileo makes use of a mental experiment with extraordinary simplicity and power of abstraction, proving that an abandoned stone from the top of a boat's mast would always fall at the foot of the mast, describing the vertical trajectory $A B$, with the boat at rest or moving with constant speed, when observed by an observer on board, while another observer on the shore would see it describe a downward curve following the horizontal displacement of the boat. In both cases, the two observers would find that the stone reaches the deck of the boat in exactly the same place, relative to the mast (Figure 03). Similarly, if abandoned from the top of a tower, the stone would always fall at the base of the tower, whether the Earth moved or not (Figure 04).

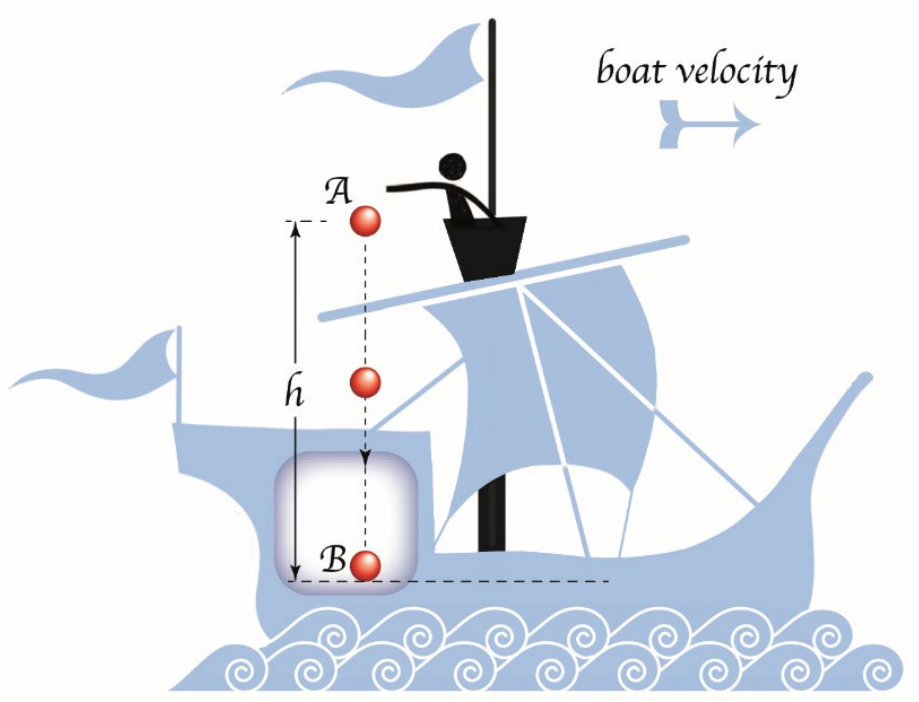

Figure 3: Theoretical experiment proposed by Galileo to argue against the immobility of the Earth defended by the scientific community in force at the time. For Galileo, the Earth has the same behaviour as boat in his a priori mental experiment. (Illustration from authors)

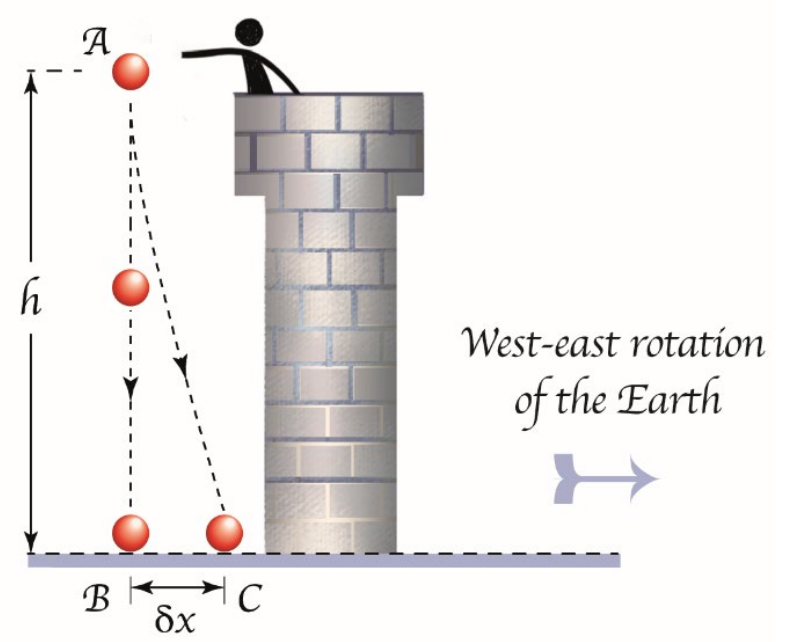

Figure 4: An abandoned stone from a tower will fall vertically at its base (path $A B$ ). If the Earth's rotation is considered, a small deviation $\delta x$ in the path caused by the Coriolis force will be observed resulting in the $A C$ curve path, negligible for practical purposes. (Illustration from authors) 
It is important to note that, in both cases, the effect of the Earth's rotation will produce a small lateral displacement of the stone in relation to the vertical ( $A C$ trajectory of Figure 04), a consequence of the Coriolis force, given by [11], [12]:

$$
\delta x=\frac{1}{3} \Omega g\left(\frac{2 h}{g}\right)^{\frac{3}{2}} \sin \theta
$$

Where $\Omega=7.3 \times 10^{-5} \mathrm{rad} / \mathrm{s}$ is the angular velocity of the Earth; $g=9.81 \mathrm{~m} / \mathrm{s}^{2}$ is the acceleration of local gravity; $h=$ height of the tower and $\theta=$ collatitude of the place where the experiment is being carried out. Disregarding the air resistance, for $h=100 \mathrm{~m}$ and $\theta=90^{\circ}$ (equator), $\delta x=2.2 \mathrm{~cm}$, equivalent to a deflection of $0.013^{\circ} \approx 47$ arc seconds ${ }^{2}$. This result, although measurable, can be neglected for practical purposes and does not invalidate Galileo's reasoning, which remains remarkable and brilliant.

Another experiment that supports Koyrè's thesis is Galileo's argument about the natural state of bodies. According to him, the natural state was the movement and not rest, in direct confrontation with the Aristotle ideas defended by the heralds of knowledge based on dogmas and authority.

For that, Galileo imagined a perfectly smooth, ideal inclined plane, without any agent that impedes the movement of a perfect sphere that would roll over it. In his mental experiment, another plane of varying inclination would extend the movement of the sphere [8]. Under identical initial conditions, the sphere would logically travel a determined distance until it stopped, reaching the same height in the second plane as it was initially released in the first. Progressively reducing the slope of the latter, the distance travelled would be increasingly greater and, at the limit, when it was completely horizontal, the sphere would continue to move indefinitely, preserving its state of motion in an attempt to reach the height from which it was released (Figure 05).

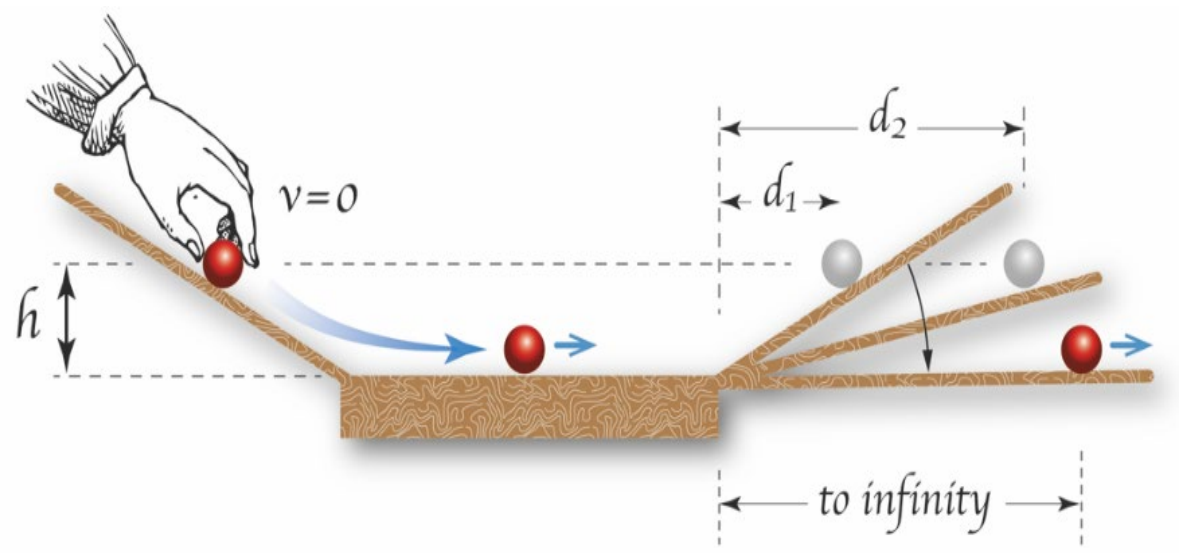

Figure 5: Experiment devised by Galileo to refute the thesis of the bodies' natural immobility. The sphere tends to remain in motion in an attempt to reach the initial launch height $(h)$, resulting in perpetual motion if the surface on the right were horizontal. Rest would come from the influences that hinder movement. (Illustration from authors)

This is yet another mental experiment designed by Galileo, since the technology available at the time prevented (as it still does today) the construction of absolutely smooth, perfect, ideal plates and spheres, eliminating all sorts of imperfections and resistive elements. From that experiment, he overturns the natural concept of immobility and announces what would later be known as the Principle of Inertia enunciated by Isaac Newton in his Principia ${ }^{3}$ [13].

\footnotetext{
2 Interestingly, Newton had predicted a similar deflection, verified experimentally by Robert Hooke, although Coriolis' force was complet.ely unknown at the time [11].

3 The Mathematical Principles of Natural Philosophy (Philosophiæ Naturalis Principia Mathematica, also referred to as Principia Mathematica, or simply, Principia) is a three-volume work written by Isaac Newton, published on July 5, 1687. Newton published two other editions, in 1713 and 1726.
} 
In the development of his thinking, Koyrè despises or underestimates the confrontation with the empirical, that is, he substitutes the experience of common sense with a priori experiments ${ }^{4}$ endowed with a deep rational interpretation, relegating the role of experience to a second plane [10]. As he himself states:

"The way in which Galileo conceives a correct scientific method implies a predominance of reason over simple experience, substituting an empirically known reality for ideal (mathematical) models, the primacy of theory over facts. Only in this way can the limitations of Aristotelian empiricism be overcome and the true experimental method can be worked out" [14].

Koyrè further argues that observation or experience, in the sense of spontaneous experience or common sense, did not play a larger role or if it did, it was a negative role in the foundation of modern science. He further states that it was not the experience, but the experimentation that played a positive and considerable role [15].

\subsection{EMPIRICISM}

In the defence of Empiricism Stillman Drake stands out as one of the most important and productive representatives of the empiricist conception of science. The striking feature of his works is associated with the belief in the pre-weighting role of experience as a path to natural truth.

Drake is concerned with distinguishing the experience of everyday life from that which advances science. For him, the experience must be associated with measurements and calculations: "The new basis for the science of Galileo's movement was carefully measured, by which he began to replace the old search for causes with the modern search for the laws of Physics" [16].

He further states that Galileo's physics was based on his own real calculations, in addition to the talent and precision of his measurements. These procedures, led him to elaborate the law of fall of the serious ones.

To legitimize his point of view, Drake refers to the text in which Galileo, on the third day of the Discorsi ${ }^{5}$, describes the famous experiment of the inclined plane. In this experiment, Galileo makes an association between the movement of vertical fall of a sphere, and its movement rolling on an inclined plane with almost no friction. The plane plays the role of a gravity "thinner" (Figure 06).

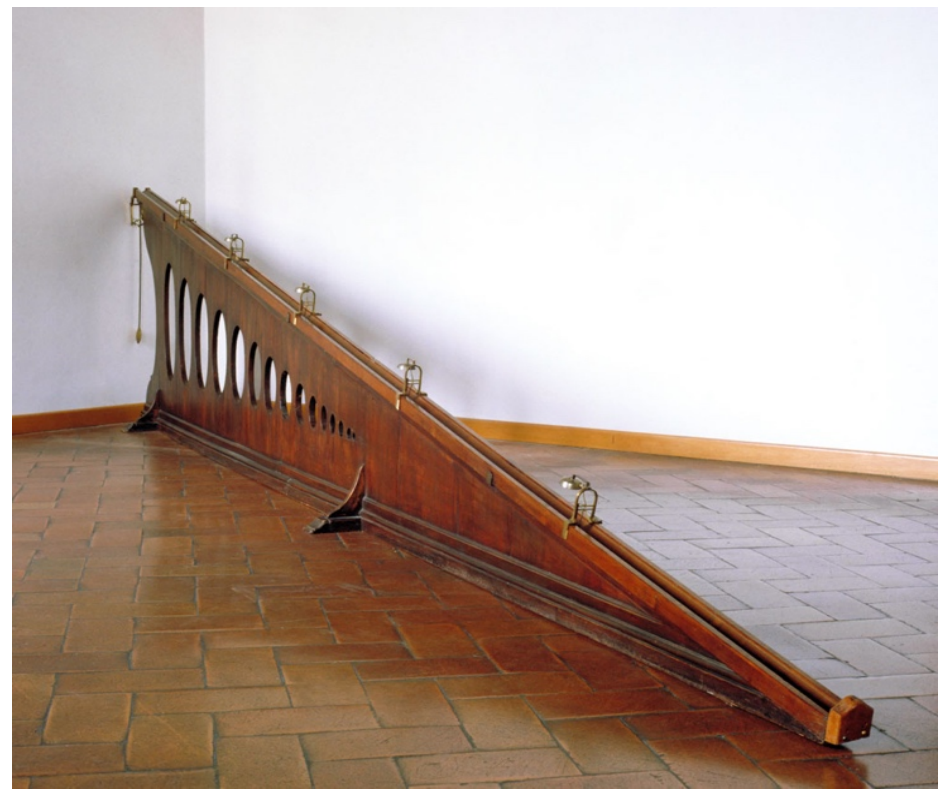

Figure 6: Experimental apparatus used to study the phenomenon of the loss of bodies. With this device, Galileo was able to transform a very fast vertical fall movement into a slower one, making it possible to take measurements with the instruments then available. Source: IMSS - Firenze.

\footnotetext{
4 Experimentation, or Experimentum, scientific activity coated with a high content of abstraction and logical-co-mathematical reasoning, materialized by well-planned and well-executed experiments in order to prove hypotheses elaborated within the scope of the mind.

$\mathbf{5}$ In Discourses on the two new sciences (Discorsi and Dimostrazioni Matematiche intorno a due Nuove Scienze), published in 1638, Galileo describes his research on the local movement of bodies.
} 
For Drake, the experience performed by Galileo was the source that provided the measures, or the understanding of the reality that was being studied, with mathematics playing a restricted role in the formulation of the Physical laws that explained the phenomenon. Drake relegates to the background the role of mathematics in drafting natural laws. Mathematics would be merely a tool, while physical laws are developed from precise measurements and observations. Experimental praxis for Drake is the key to understanding Nature.

\section{DISCUSSION}

The interpretation of the Galilean scientific legacy from the rationalism defended by Koyrè or the empiricism defended by Drake contributes only in an attempt to find the correct position on the methodological practice followed by Galileo in the development of his Physics. Although both have based their work on judicious and reliable research, their positions about Galileo's way of doing science have opposite, antagonistic, asymmetric biases. The validity of the first method suppresses and invalidates the second method.

Ludovico Geymonat defends a thesis in which such asymmetry is replaced by a more inclusive and conciliatory view. For Geymonat, science is mine or is based on a dialectical practice, where observation and hypotheticaldeductive reasoning merge and go hand in hand.

According to Gaymonat, the appeal to experience thus becomes an appeal to a richly articulated process in which the scientist must commit himself with all his ingenuity and technical expertise. In other words, it is not a matter of introducing into the scientific investigation a moment of mere passivity, as some epistemologists think, but of asserting the presence, essential in such research, of a type of activity focused on empirical facts, different from that purely. theoretical theory [17], [18].

Precisely for this reason, the observation process would not represent for Galileo the antithesis of mathematical elaboration: they would represent diverse and complementary phases, not opposed to scientific research that is always fundamentally active in all its complex and difficult realization.

Throughout the creation process, Galileo combined his manual skill with creative ability. These attributes led to the improvement of the telescope and the numerous technical instruments, such as the military compass. He was also able to understand the unquestionable merit brought by mathematics and understood that any successful application of scientific theories would constitute concrete proof of its validity [19].

The successive advances in science and technology have broadly confirmed his intuition, that is, that science, when facing the questions raised by technique, does not only fulfil a practical function, but also a theoretical one: each time it manages to solve one of these questions, pursues with this a success that is soon reflected in all science and, on the contrary, when he has to confess himself unable to solve it, he is obliged to review and find out what led the technician to an erroneous or imprecise solution [20].

In Galileo's intellectual identity, a peculiar attribute of transiting or transposing freely between the two methodological instances is perceived, characteristic of free, powerful and brilliant minds.

\section{CONCLUSION}

The Galilean way of doing science is very controversial. Considered almost unanimously as the father of modern science, many commentators on his work interpret his legacy from a methodological, self-contained view, often full of passions and inability to discuss the contradictory and without considering the details of his work. time, his specific needs and influences that would profoundly shape his way of thinking.

Based on this observation, commentators on his work, by way of Ludovico Geymonat, provide a less exclusive way of interpreting the Galilean legate. Galileo's rich imagination made it possible to use two methodological devices, the rational and the empirical, in an indistinct manner, and it was up to his intuition to choose the correct moment of transposition. Therein lay his genius.

\section{SOURCES OF FUNDING}

This research received no specific grant from any funding agency in the public, commercial, or not-for-profit sectors. 


\section{CONFLICT OF INTEREST}

The author have declared that no competing interests exist.

\section{ACKNOWLEDGMENT}

None.

\section{REFERENCES}

[1] McNEESE, T. Galileo. Renaissance Scientist and Astronomer. Chelsea House Publishers, Phila-delphia. 2006.

[2] SETTLE, T. B. La rete degli esperimenti galileiani. In Galileo e la scienza sperimentale. Padua: Dipartimento di Fisica "Galileo Galilei", 11-62.

[3] KHUN, T. A Estrutura das Revoluções Científicas. Perspectiva Editora, São Paulo, 1997.

[4] VALLERIANI, M. Galileo Engineer. Boston Studies in the Philosophy of Science, v. 269. Springer, 2010.

[5] ASARI, G. Le vite de' più eccellenti pittori, scultori e architettori. Firenze: Giunti, 1568.

[6] GALILEI, G. Duas novas Ciências - Do título original: Discorsi e Dimostrazioni Matematiche intorno a due Nuove Scienze atteneti ala Mecanica ed a i Movimenti Localli. Tradução: Pablo MARICONDA. Nova Estela Editora, São Paulo, 1988.

[7] GASSET, J. O. In Torno a Galileo. Colecion Austral. Madrid. 1965.

[8] BATALLA, N.B. Galileo Ingeniero y la libre investigación. Fondo de Cultura económica. México. 1995.

[9] COPÉRNICO N. As Revoluções dos Orbes Celestes - Do título original: De Revolutionibus Orbium Celestium Fundação Calouste Gulbenkian. Lisboa, 1984.

[10] KOYRÉ, A. Estudos Galiláicos. Editora Dom Quixote - Lisboa, 1986.

[11] FROVA, A. \& MARENZANA, M. Thus, Spoke Galileo. The Great Scientist's Ideas and Their Rele-vance to the Present Day. Oxford University Press. New York, 2006.

[12] TAYLOR, J. R. Classical Mechanics. University Science Books, California, 2005.

[13] NEWTON, I. - Princípios Matemáticos de Filosofia Natural. Nova Estela - EDUSP. São Paulo. 1990.

[14] KOYRÉ, A. Do Mundo Fechado ao Universo Infinito. Gradiva - Lisboa- 1961.

[15] KOYRÉ, A. Estudos e História do Pensamento Científico. Editora Forense Universitária, Rio de Janeiro, 1991.

[16] DRAKE, S. Galileu. Editora Dom Quixote - Lisboa, 1981.

[17] GEYMONAT, L. Rifflessione Critiche su Khun e Popper Bari. Dédalo, Itália, 1984.

[18] GEYMONAT, L. Galileu Galilei Editora Nova Fronteira Rio de Janeiro, 1997.

[19] GEYMONAT, L. \& GIORELLO G. As Razões da Ciência. Edições 70 Lisboa - 1986.

[20] ARAÚJO FILHO W. D. A Gênese do Pensamento Galileano. Livraria da Física Editora. São Pau-lo, 2008. 